\title{
PEMANTAPAN DIMENSI ETIKA DAN ASAS SEBAGAI PENGUATAN SISTEM HUKUM LINGKUNGAN DI INDONESIA
}

\author{
Himas Muhammady Imammullah el Hakim \\ Magister Ilmu Hukum, Fakultas Hukum, Universitas Indonesia, Indonesia, \\ himas.muhammady@ui.ac.id (corresponding).
}

\begin{abstract}
Humans as social beings who use the environment make the law an instrument of regulation and protection. Laws relating to the environment itself systemically provide both general and specific regulation. However, environmental law instruments still require further development through strengthening of the ethical dimension. Ethics as one of the norms that can be codified and processed through the judiciary can strengthen the implementation of environmental law. The study was conducted by means of a literature study and analysis in order to find ethical positions and opportunities in the environmental law system. The Job Creation Act which directly changes the politics of environmental law certainly presents its own challenges. This development requires encouragement from other systems, one of which is ethics by presenting a positive ethical system as a law of ethics, both code of ethics and court of ethics. ethical law system that specifically regulates environmental law then requires general principles so that the ethical law instrument can take shape and be applied properly. There are several general principles of environmental law ethics, including the principle of clarity of purpose, the principle of independence, the principle of justice, the principle of certainty, the principle of benefit, the principle of balance, the principle of openness and the principle of protection. The challenge of implementing the general principles of environmental law ethics is in both substantial and formal dimensions that can be encouraged by the holders of power as constitutional mandates in the context of realizing the ideals of the state through the implementation of the mandate of the MPR Decree VI/MPR/2001 concerning the Ethics of the Nation's Life.
\end{abstract}

Keywords: General Principles; Legal ethic; Environmental Law

\section{PENDAHULUAN}

Hukum merupakan bagian yang tidak terpisahkan dari eksistensi manusia. Hal ini sejalan dengan adagium ubi societas ibi ius yang bermakna dimana ada manusia disitu ada hukum. Kepentingan-kepentingan beragam dari manusia baik secara personal maupun publik membutuhkan instrumen untuk memoderasi agar tidak ada yang dirugikan sekaligus menjadi titik temu antar kepentingan serta membatasi ruang perilaku manusia agar tujuan bermasyarakat dapat terwujud. Instrumen inilah yang disediakan oleh hukum dengan tujuan-tujuan idealnya baik mencapai keadilan, kebermanfaatan, kepastian hingga kedamaian dalam bermasyarakat. Norma hukum (legal norm) yang merupakan standar-standar yang termaktub dalam produk hukum dengan variasinya baik tertulis seperti konstitusi dan peraturan perundang-undangan maupun tidak tertulis seperti konvensi ketatanegaraan secara konkret menjadi instrumen yang memberikan pengaturan sekaligus perlindungan dalam bermasyarakat. Akan tetapi norma hukum tentu tidak dapat berdiri sendiri secara independen tanpa dipengaruhi oleh norma-norma lain yang juga 
memiliki keberlakuan ditengah masyarakat. Norma agama, norma kesusilaan dan norma etika merupakan beberapa norma penting yang berkelindan dengan norma hukum dalam mewujudkan tujuan normatifnya pada masyarakat baik secara materiil maupun formil. Norma-norma itulah yang memiliki peran yang sama dalam bentuk etika.

Etika yang berasal dari bahasa yunani ethos dengan makna karakter, sifat dasar maupun watak yang secara umum bagaimana tindakan yang diharapkan dari seseorang (Ward, 2011). Terdapat beragam tujuan dari etika seperti pendapat Aristoteles tercapainya kebaikan dan kebahagiaan (Aristotle, 2000) yang dikaitkan dengan peran dari ilmu pengetahuan termasuk penetahuan tentang apa yang baik (good). Selain itu tujuan etika menurut W.D Ross dapat diklasifikasikan dengan pengertian (1) the right act yang bermakna tindakan yang benar dan (2) morally good action atau perilaku yang baik secara moral (Ross \& Stratton-Lake, 2007). Peranan etika juga memberikan batasan maupun pengaturan terkait dengan hal-hal yang dianggap baik termasuk menetapkan hal yang ideal (Moore, 2002). Hal inilah yang secara teleologis dapat dimaknai sebagai bagian dari tujuan dari norma etika yang berfungsi menjadi the true north atau arah penunjuk jalan yang ideal bagi masyarakat dengan nilai-nilai ideal dan normatifnya yang diharapkan masyarakat tunduk secara sadar untuk mewujudkan hal-hal tersebut baik dengan melakukan atau tidak melakukan suatu perbuatan. Al Ghazali berpendapat bahwa moralitas atau etika merupakan norma yang dapat dipahami sendiri oleh manusia dan secara sadar sebagai makhluk berakal memilih etika sebagai salah satu bimbingan atau pedoman sebagai bagian alami insani (Quasem, 1988). Hal ini menunjukkan bahwa secara asasi, kecenderungan manusia termasuk masyarakat (society) pasti memiliki norma etika yang hidup dan mengikat diantara mereka bergantung pada dimensi lain seperti agama, budaya, pendidikan, politik, ekonomi dan sebagainya.

Manusia sebagai makhluk yang memiliki kehendak bebas menurut Samuel Pufendorf memiliki pilihan untuk bertindak etis atau bermoral (moral action) yang terdiri dari tiga elemen (Pufendorf, 2009) yakni pertama ialah material, yaitu adanya perbuatan tertentu yang nyata, kemudian unsur kedua yang fundamental yakni reason atau alasan berbuat, dan ketiga aspek formal yang merupakan tindakan yang diperbuat. Tiga elemen tindakan etis manusia tersebut secara langsung menunjukkan bahwa masyarakat sebagai institusi sosial dari manusia tidak lepas dari perilaku-perilaku yang dilandasi oleh suatu alasan tertentu (mens rea) yang secara faktual bersinggungan dengan hukum yang mengikatnya. Norma etika sebagai salah satu norma yang memiliki keberlakuan dan eksistensi yang dapat dikatakan senapas dengan keberadaan hukum memberikan ruh pada masyarakat dalam menjalankan peran tugas dan fungsinya. Maka dari itu peran etika dalam sistem hukum khususnya hukum lingkungan dapat memperkuat implementasinya secara konsisten.

\section{HASIL DAN PEMBAHASAN}

\section{Relasi Etika dan Hukum serta Gagasan Hukum Etika}

Terdapat beberapa unsur-unsur penting yang membentuk hukum yakni (1) adanya suatu peraturan, (2) kehendak dari pihak otoritatif yang juga sejalan dengan definisi Holland tentang hukum yakni aturan umum atas perilaku eksternal (konkret) manusia yang ditegakkan oleh otoritas politik yang berdaulat (French, 1893). Hal ini juga senada dengan pendapat Agus Santoso bahwa hukum meliputi beberapa unsur yakni (1) peraturan mengenai tingkah laku manusia dalam 156 | Article History, Submitted 10 September 2021 - Revision Required 19 September 2021 - Accepted 30 September 2021. 
bermasyarakat, yang (2) diadakan oleh badan-badan resmi yang berwajib, dengan (3) sifat yang memaksa dan memiliki (4) sanksi tegas terhadap pelanggaran (Santoso, 2012).

Berdasarkan unsur-unsur tersebut terdapat hal yang harus ada dalam hukum yakni sanksi atau hukuman oleh pihak yang berwenang terhadap pelanggar yang melanggar suatu peraturan. Pelembagaan hal ini secara konkret ditunjukkan dengan adanya institusi penegak hukum dengan kewenangan mulai dari memeriksa, menuntut dan mengadili termasuk menegakkan sanksi atas putusan tersebut. Lembaga seperti kepolisian, kejaksaan, pengadilan termasuk advokat maupun institusi lain dengan kewenangan yang sejenis, menjadi instrumen penting dalam sistem hukum agar dapat ditegakkan dengan seadil-adilnya.

Moralitas yang juga terkandung dalam norma etika secara substansial menekankan pada baik buruk dari suatu perbuatan. Hal ini juga sejalan dengan norma hukum yang secara positifistik berperan dalam menentukan standar baik atau buruk didasarkan pada otoritas. Persamaan antara norma etika dan norma hukum dalam hal menjadi kompas baik buruk menjadi titik temu antara kedua norma tersebut terlebih moralitas sendiri merupakan landasan dari tujuan hukum (Marzuki, 2013). Selain itu norma etika sendiri menurut Jimly Asshiddiqie (Asshiddiqie, 2009) merupakan sumber dalam proses pembentukan norma hukum yang kemudian dikukuhkan atau dipositifkan oleh kekuasaan negara melalui lembaga-lembaganya baik secara eksekutif, legislatif dan yudisial.

Hukum sebagai standar yang mengatur perilaku masyarakat tidak dapat dipungkiri memiliki batasan-batasan yang dapat melampaui ambang batas moralitas (Luban, 2007). Pembatasan yang diatur oleh norma hukum terikat secara positif melalui pengaturan oleh institusi yang memiliki otoritas untuk mengeluarkan produk hukum. Kepastian hukum yang terkodifikasi pada produk hukum kenyataannya tidak serta merta menghadirkan pemahaman yang universal dan seragam atas suatu aturan atau dengan kata lain interpretasi maupun penafsiran atas hukum yang juga beragam kemudian melahirkan peluang-peluang aplikasi hukum yang juga lebih variatif. Batasan yang secara positif diatur dalam produk hukum kemudian melahirkan pemahaman legalitas, yang secara sederhana bermakna selama tidak dilarang maka diperbolehkan.

Pemisahan antara hukum dengan moral atau etika tidak dinafikan merupakan perdebatan panjang dari dua pandangan antara penganut hukum alam yang dominan merujuk pemikiran Thommas Aquinas vis a vis dengan hukum positivistik dengan John Austin dan Jeremy Bentham sebagai tokoh rujukannya. Namun pada prinsipnya eksistensi norma moral atau etika bersinggungan dengan norma hukum pada implementasinya di masyarakat. Hal ini berarti jika didasarkan pada konsep sosial dari hukum, keberadaan dan kandungan dari hukum ditentukan oleh fakta-fakta sosial yang selanjutnya menjadi law-determining facts atau fakta-fakta yang menentukan hukum (Lyons, 1984).

Hubungan antara hukum dan etika sebagai norma memang tidak dapat disamakan secara apple to apple mengingat keduanya juga memiliki perbedaan yang bersifat fundamental. Akan tetapi tidak dapat dipungkiri bahwa norma etika sendiri merupakan kandungan yang dibutuhkan dalam norma hukum dan hukum merupakan bentuk implementatif yang diperlukan etika secara implementatif (Bondolfi \& Nye, 2000). Hal inilah yang menjadikan hukum sebagai instrumen untuk mengatur aktifitas dari masyarakat bahkan sekalipun terdiri dari individu yang bermoral dengan catatan penting bahwa praktik hukum dan moral atau etika dipengaruhi secara drastis oleh perbedaan entah itu berupa konflik kepentingan hingga ketidaksepakatan (Soper, 2002).

Aplikasi atau implementasi dari norma etika inilah yang memerlukan dan berhubungan langsung dengan norma hukum sehingga membentuk norma yang bersifat sintesis yakni hukum 
etika. Hukum etika sebagai hukum yang bersifat sistemik (rule of ethics) memerlukan dua perangkat yang penting yakni kode etik (code of ethics) dan pengadilan etika (courts of ethics) (Asshiddiqie, 2015) agar secara konkret dapat di implementasikan pada masyarakat. Norma etika sebagai memerlukan kedua hal tersebut agar dapat menjalankan fungsinya sebagai applied ethics.

Secara definitif applied ethics menurut Michael Head dan Scott Mean merupakan bentuk penerapan prinsip dan gagasan umum atas pengambilan keputusan yang berlandaskan etika pada hal yang kontekstual konkret pada aktifitas profesional tertentu seperti medis, bisnis, penelitian, pendidikan hingga hukum (Head \& Man, 2005). Pendapat tersebut secara tersirat menunjukkan bahwa pada bidang-bidang masyarakat yang memiliki peranan strategis dan berdampak seperti kedokteran termasuk hukum memerlukan etika yang dibungkus secara aplikatif melalui hukum agar kegiatan profesional tersebut dapat mencapai tujuannya. Konsep hukum etika yang terkandung dalam applied ethics yang memerlukan norma materiil dan norma formil sebagai unsur yang membentuk norma hukumnya penting untuk

Terdapat hal yang juga penting untuk dibahas terkait dengan relasi antara hukum dengan etika yakni pluralisme hukum maupun pluralisme etika. Norma hukum dan norma etika tidak dapat dipungkiri memiliki pluralitas yang terikat oleh waktu dan tempat. Hukum yang berlaku di suatu negara sangat berbeda dengan negara yang lain pun etika antar negara yang berbeda satu sama lain sesuai dengan nilai-nilai yang membentuknya. Hal inilah yang menjadikan pentingnya menggunakan perspektif multidimensi dalam memandang relasi antara hukum etika baik secara filosofis, historis, politis hingga sosiologis.

Sebagai perbandingan, pada konteks etika medis Islam menurut Darius Atighechi terdapat dua faktor yang berpengaruh dalam pluralisme atau keberagaman interpretasi dari suatu etika yakni pertama (1) dorongan sentrifugal, dengan mendasarkan segala nilai etika pada sumber hukum Islam (Al Qur-an dan As Sunnah) dan (2) dorongan sentripetal dilahirkan dari adaptasi dan penemuan pada perbedaan konteks yang juga disebabkan tidak adanya otoritas terpusat (Atighetchi, 2007). Jika menggunakan perspektif Darius maka dua faktor baik sentrifugal dan sentripetal dalam penentuan hukum etika juga terjadi dimana saja.

Pada konteks relasional antara norma etika khususnya dengan hukum lingkungan, maka hal ini juga sebagaimana penulis paparkan bahwa hukum lingkungan memerlukan norma etika baik secara materiil maupun formil dalam rangka mewujudkan penegakkan hukum lingkungan yang lebih komprehensif dan holistik. Urgensi intervensi norma etika yang dipositifkan dalam hukum lingkungan secara aplikatif diharapkan mampu mendorong pelaksanaan serta implementasi hukum lingkungan oleh seluruh pemegang kepentingan secara serius melalui code of ethics dan court of ethics. Kedua elemen tersebut penting untuk dikaji, dikembangkan termasuk diaplikasikan lebih lanjut dalam sistem hukum lingkungan agar hukum yang ditegakkan oleh aparatur, badan, lembaga maupun otoritas yang berwenang secara optimal dan berkualitas menghasilkan produk hukum atau kebijakan yang mewujudkan cita hukum lingkungan.

Kajian ini meskipun tidak membahas secara lebih lanjut dan mendalam terkait dengan code of ethics dan court of ethics dalam ranah hukum lingkungan, namun lebih mengulas pada hal yang lebih esensial yakni asas-asas yang menjadi etika hukum lingkungan. Asas-asas inilah yang diharapkan mampu menjadi landasan fundamental sekaligus filosofis atas sistem etika hukum lingkungan baik secara materiil dalam segala peraturan perundang-undangan termasuk code of ethics dan secara prosedural pada penegakkan hukum oleh otoritas yang berwenang dalam court of ethics hukum lingkungan.

158 | Article History, Submitted 10 September 2021 - Revision Required 19 September 2021 - Accepted 30 September 2021. 
Hal yang juga perlu penulis sedikit ulas adalah ada perbedaaan mendasar antara "asas hukum lingkungan" dengan "asas etika hukum lingkungan" serta "Asas etika lingkungan". Secara bahasa dan sederhana sendiri ketiga istilah tersebut menunjukkan kata mana yang berperan secara umum dan khusus termasuk diterangkan-menerangkan. Asas hukum lingkungan menunjukkan bahwa asas-asas ini harus ada dan membentuk identitas dari hukum lingkungan. Kemudian asas etika lingkungan berarti asas tersebut merupakan bentuk etika atas lingkungan dengan makna yang luas baik pada secara hukum, politik, ekonomi hingga sosial. Sementara asas etika hukum lingkungan sendiri menurut penulis adalah asas-asas yang menjadi landas fundamental atas sistem etika baik code of conduct maupun court of conduct yang diaplikasikan secara lebih konkret oleh hukum lingkungan. Hal inilah yang penulis akui masih memerlukan pembahasan dan diskusi lebih lanjut terkait dengan istilah yang digunakan namun tidak mengurangi esensi pembahasan terkait etika dan hukum lingkungan beserta asas-asasnya pada penelitian ini.

\section{Asas Hukum Lingkungan}

Pada lingkup peraturan perundang-undangan dalam undang-undang khususya yang mengatur secara khusus tentang lingkungan hidup dicantumkan beberapa asas atau prinsip lingkungan hidup. Secara historis dan kronologis terdapat beberapa perubahan dan perkembangan dalam pembahasan terkait asas atau prinsip hukum lingkungan hidup.

Sebagaimana contohnya pada ketentuan Pasal 3 Undang-Undang Nomor 4 Tahun 1982 tentang Ketentuan-ketentuan Pokok Pengelolaan Lingkungan Hidup yang menyebutkan bahwa pengelolaan lingkungan hidup berasaskan pelestarian kemampuan lingkungan yang serasi dan seimbang untuk menunjang pembangunan yang berkesinambungan bagi peningkatan kesejahteraan manusia. Frasa dari pasal tersebut menunjukkan ada 3 (tiga) asas yang penting dalam ketentuan tersebut yakni :

1. Pengelolaan lingkungan hidup berasaskan pelestarian kemampuan lingkungan yang serasi dan seimbang;

2. Menunjang pembangunan yang berkesinambungan; dan

3. Peningkatan kesejahteraan manusia.

Penulis berpendapat bahwa asas pertama bermakna asas keserasian dan keseimbangan, asas kedua adalah pembangunan berkelanjutan dan asas ketiga adalah asas kebermanfaatan dan kesejahteraan.

Undang-Undang berikutnya yakni Undang-Undang Nomor 23 Tahun 1997 tentang Pengelolaan Lingkungan Hidup mengatur terkait dengan asas hukum lingkungan pada ketentuan Pasal 3 sebagaimana termaktub bahwa pengelolaan lingkungan hidup yang diselenggarakan dengan asas tanggung jawab negara, asas berkelanjutan, dan asas manfaat bertujuan untuk mewujudkan pembangunan berkelanjutan yang berwawasan lingkungan hidup dalam rangka pembangunan manusia indonesia seutuhnya dan pembangunan masyarakat Indonesia seluruhnya yang beriman dan bertaqwa kepada tuhan yang maha esa. Secara garis besar ketentuan ini mengandung 4 (empat) asas hukum lingkungan yakni :

1. Asas tanggung jawab negara;

2. Asas berkelanjutan;

3. Asas manfaat;

4. Asas pembangunan berkelanjutan. 
Pengaturan terkait dengan prinsip tersebut pada Undang-Undang Nomor 32 Tahun 2009 tentang Perlindungan dan Pengelolaan Lingkungan Hidup diatur dalam ketentuan Pasal 2 yang berbunyi bahwa perlindungan dan pengelolaan lingkungan hidup dilaksanakan berdasarkan asas :
a. Asas tanggung jawab negara;
b. Asas kelestarian dan keberlanjutan;
c. Asas keserasian dan keseimbangan;
d. Asas keterpaduan;
e. Asas manfaat;
f. Asas kehati-hatian;
g. Asas keadilan;
h. Asas ekoregion;
i. Asas keanekaragaman hayati;
j. Asas pencemar membayar;
k. Asas partisipatif;
1. Asas kearifan lokal;
m. Asas tata kelola pemerintahan yang baik;
n. Asas otonomi daerah.

Undang-Undang Nomor 11 Tahun 2020 tentang Cipta Kerja khususnya pada bagian paragraf 3 yang merubah beberapa ketentuan dalam Undang-Undang Nomor 32 Tahun 2009 tentang Lingkungan Hidup tidak memberikan pengaturan yang mengganti Pasal 2 dari undang-undang sebelumnya. Hal ini berarti keberlakuan dari 14 (empat belas) asas masih memiliki keberlakuan.

Jika ditelaah secara komparatif memang terjadi perkembangan dalam pengaturan asas hukum lingkungan dari Undang-Undang Nomor 4 Tahun 1982 dengan 3 asas, Undang-Undang Nomor 23 Tahun 19974 (empat) asas hingga Undang-Undang Nomor 32 Tahun 2009 secara drastis menjadi 14 (empat belas) asas. Hal ini menunjukkan bahwa telah terjadi perkembangan yang cukup baik dan konstruktif dalam rangka penegakkan hukum lingkungan secara komprehensif dan holistik baik yang terintegrasi dengan norma yang berlaku secara internasional maupun secara lokal. Asas-asas inilah yang secara konkret harus diakomodasi dan terkandung dalam asas-asas norma etika pada hukum lingkungan.

Hukum lingkungan sendiri memiliki beberapa asas-asas yang disarikan dari pelbagai perspektif baik global dan lokal sehingga terdapat beberapa prinsip atau asas hukum lingkungan sehingga secara universal dapat diterima sebagaimana berikut (Syarif \& Wibisana, 2015) :
1. Sustainable Development
2. Inter-generational Equity
3. Intra-generational Equity
4. Polliter Pay principle

5. Principle of Preventive Action

6. The Precautionary Principle

7. Sovereign Rights and Environmental Responsibility

8. Access to Environmental Information, Public Participation in Environmental Decision, Equal Access and Non-Discrimination

Kedelapan asas tersebut secara substansial sebenarnya terkandung maupun memiliki keterkaitan dengan asas-asas yang diatur pada undang-undang sebagai instrumen hukum di Indonesia. 


\section{Gambar 1 : Relasi Asas Hukum Lingkungan dan Asas Etika Hukum Lingkungan}

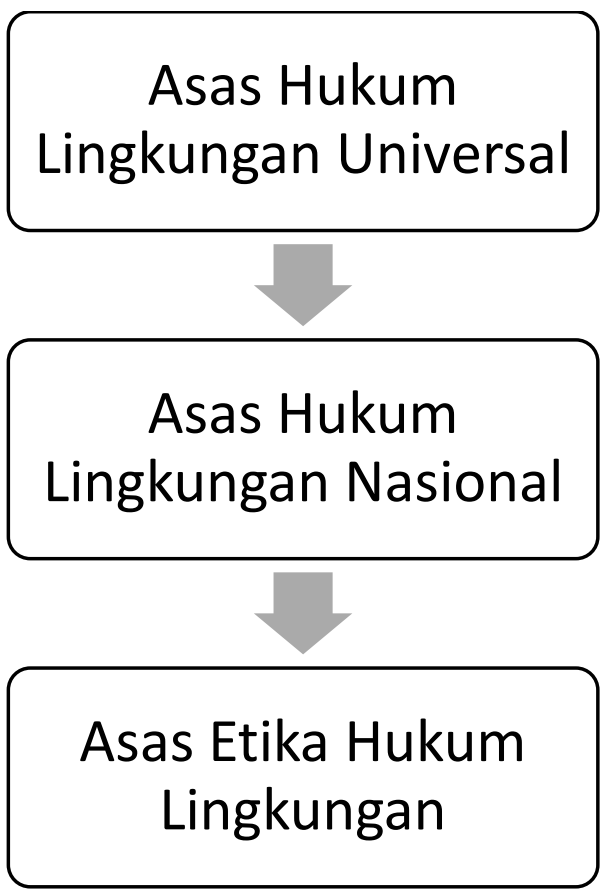

\section{Asas-Asas Umum Etika Hukum Lingkungan}

Jimly Asshiddiqie berpendapat perihal etika bahwa dalam suatu peraturan perundangundangan tidak hanya mengatur terkait prosedur penegakannya saja namun juga perlu mengatur terkait dengan sebagian materi dari etika yang setidaknya berkaitan tentang prinsip-prinsip norma etika yang bersifat umum dan abstrak (Asshiddiqie, 2015). Perspektif yang juga menjadi salah satu landasan dalam kajian ini menunjukkan pentingnya menggali dan membentuk prinsip atau asas norma etika bersifat umum dan abstrak tersebut dalam rangka meneguhkan posisi hukum etika atau etika fungsional yang dipositifkan melalui peraturan perundang-undangan. Pendapat dari Jimly tersebut juga menjadi titik landasan yang cukup berarti dalam rangka menemukkan asasasas apa saja yang penting dalam rangka membangun instrumen hukum etika yang lebih komprehensif dan sistemik.

Hukum etika sebagai instrumen yang penting dalam ekosistem masyarakat memerlukan fundamental yang befungsi sebagai batasan norma yang sebagaimana telah dipaparkan sebelumnya terkait dengan tindakan dan perilaku dari suatu institusi maupun profesi tertentu. Eksistensi dari asas hukum etika menjadi penting sebagaimana peran asas hukum pada umumnya dalam penyelenggaraan rule of ethics. Posisi asas dan prinsip dalam hukum sebagai sistem merupakan pemberi identitas normatif dan filosofis dari sistem hukum. Hal ini disebabkan selain sifat asas yang universal juga asas hukum mencerminkan tata nilai dan pesan kultural yang diwujudkan oleh hukum itu sendiri.

Norma hukum sebagai salah satu norma yang membentuk hukum etika memiliki peran penting dalam penyusunan asas-asas etika sebagai rule of ethics. Asas-asas dalam norma hukum 
secara faktual memiliki relevansi pada hukum etika mengingat etika sendiri merupakan salah satu norma yang beririsan dengan

Jika ditinjau dari sifatnya terdapat dua jenis asas-asas hukum etika yakni :

1. Asas hukum etika substansial;

2. Asas hukum etika formal.

Asas hukum etika substansial sebagaimana makna dari sifatnya, substansi, memberikan landasan penting bahwa kandungan dari hukum etika harus memiliki relevansi baik secara filosofis maupun sosiologis. Asas ini secara praktis menitikberatkan pada pentingnya menyusun perangkatperangkat hukum etika baik peraturan maupun peradilannya secara relevan. Sementara itu asas hukum etika formal berfokus pada urgensi mengawal proses penegakkan hukum etika yang sesuai dengan tujuannya. Kode etik sebagai peraturan hukum etika yang telah mengandung asas-asas substansial tidak memiliki arti jika tidak dikawal secara formil dan hal inilah yang ditekankan dengan eksistensi asas hukum etika secara formal.

Adapun berdasarkan dari telaah atas asas hukum lingkungan tersebut, penulis merangkum beberapa asas-asas hukum etika secara subtansial baik secara materiil maupun formil dapat diklasifikasikan pada hal yang bersifat fundamental. Pengadopsian dari asas norma hukum yang secara umum memiliki keberlakuan pada umumnya merupakan hal yang niscaya mengingat fungsi norma hukum pada hukum etika adalah sebagai pembentuk (embodiment).

Tentu pasti terdapat titik singgung dan irisan antara satu asas dengan asas yang lain bahkan terdapat peluang saling kontradiksi atau bertentangan, namun hal tersebut tentu tidak mengurangi esensi maupun urgensi atas eksistensi suatu asas pada hukum.

\section{Asas kejelasan tujuan}

Segala sesuatu pasti memiliki tujuan yang hendak dicapai secara ideal termasuk hukum etika. Hal ini juga harus terkandung dalam hukum etika yang akan mempengaruhi baik institusi dan pribadi yang terikat secara langsung maupun masyarakat pada umumnya. Kejelasan tujuan dari hukum etika setidaknya dapat memberikan arah yang jelas dari implementasi penegakkan aturannya. Keberadaan dari asas ini penting dalam suatu sistem hukum mengingat diantara tujuan hukum adalah memberikan kepastian, kebermanfaatan dan ketertiban maupun tujuan lain. Artinya tujuan sebagai hal yang hendak dicapai sehingga dibentuk suatu hukum harus diterangkan secara jelas mengapa (reason why atau ratio legal) suatu aturan diberlakukan.

Hal inilah yang secra implementatif akan menghasilkan produk hukum yang lebih jelas dan terarah pada output maupun outcome produk hukum tersebut. Asas etik secara teleologis ini terkait langsung dengan seluruh asas hukum lingkungan.

\section{Asas kemandirian}

Prinsip ini berkaitan dengan sifat manusia yang mandiri (autonomy) dan bertanggungjawab atas apa yang dilakukannya secara sadar. Asas kemandirian atau yang juga bermakna independensi ini menghendaki adanya kejelasan dan kepastian dalam hal pertanggungjawaban atas suatu tindakan berbuat atau tidak berbuat yang secara langsung melanggar hukum etika. Kemandirian yang dimaksud juga berhubungan dengan bebas intervensi atau pengaruh dominan yang mempengaruhi proses penegakkan hukum etika sehingga produk hukum yang dihasilkan benar-benar mencerminkan tujuan hukum etika yang sebenar-benarnya. Asas kemandirian ini berarti memiliki keberlakuan secara prinsip baik pada peraturan hukum etika, institusi penegakkan hukum etika dan pihak-pihak yang 
terikat secara langsung dengan hukum etika. Ketiga perangkat tersebut memiliki tangung jawab dan berperan dalam mengimplementasikan asas kemandirian sesuai pada porsinya.

Pada peraturan hukum etika atau yang dikenal sebagai kode etik, materi dan substansi dari peraturan-peraturan yang terkandung didalamnya harus menghadirkan kemandirian atau independensi sehingga kehormatan hukum etika benar-benar mendapatkan penghormatan dengan ketundukkan secara sadar. Hal ini tentu akan berpengaruh pada efektifitas terutama secara preventif atas hukum etika melalui kesadaran pihak atau anggota yang tunduk langsung pada hukum etika disebabkan pemahaman bahwa hukum etika merupakan bagian yang tak terpisahkan dari identitas mereka. Kemandirian sebagai asas etika memiliki keterkaitan dan substansi yang bersinggungan langsung dengan Sustainable Development, The Precautionary Principle, dan Sovereign Rights and Environmental Responsibility.

\section{Asas keadilan}

Keadilan sebagai salah satu tujuan penting dari eksistensi hukum secara asasi tidak mungkin dinafikan porsinya sebagai asas yang fundamental. Keadilan sendiri secara pemaknaan merupakan bentuk menempatkan sesuatu pada tempatnya. Hal ini berarti keadilan dapat dimaknai secara obyektif dan tidak tunggal dengan bermakna adil adalah sama an sich melainkan adil adalah kesesuaian (just). Keadilan yang menurut Aristoteles dapat berbentuk distributif dan komutatif (Chroust \& Osborn, 1942), menunjukkan bahwa terdapat perbedaan dalam implementasi dari keadilan itu sendiri. Keadilan distributif (distributive justice) atau yang juga disebut strict justice menghendaki penanganan yang sama tanpa diskriminasi atau perbedaan. Sementara keadilan secara komutatif (comutative justice) atau yang juga bermakna proportional justice memandang perlunya perbedaan dalam putusan dari satu pihak dengan yang lain sesuai dengan porsinya. Pada konteks hukum etika, kedua jenis keadilan tersebut baik strict maupun proportional memiliki keberlakuan baik secara substansial maupun formal. Respon yang diberikan berdasarkan dari asas keadilan ini, baik yang tertuang dalam kode etik sebagai peraturan hingga proses dan putusan dari persidangan etik, harus mengaplikasikan keadilan yang tepat dan sesuai. Asas etika ini terkait langsung dengan Sustainable Development, Inter-generational Equity, Intragenerational Equity, Polliter Pay principle, dan Access to Environmental Information, Public Participation in Environmental Decision, Equal Access and Non-Discrimination.

\section{Asas kepastian}

Norma hukum yang mementuk hukum etika menghendaki salah satu tujuan hukum yakni kepastian untuk berperan menjadi asas yang penting. Hal ini disebabkan karakteristik hukum adalah memberikan kepastian in contrario menghilangkan ketidakpastian hukum yang berakibat sistemik hingga merugikan subyek hukum. Implementasi dari asas kepastian ini menegaskan dan memperkuat penerapan asas lain khususnya kejelasan tujuan.

Jika asas kejelasan tujuan menitikberatkan pada apa tujuan yang hendak dicapai dari suatu hukum etika, maka asas kepastian lebih memberikan kepastian pada instrumen lain yang penting dan harus ada agar hukum etika bisa dilaksanakan dengan optimal. Siapa pihak yang berwenang? Apa sanksi atas pelanggaran tertentu? Bagaimana prosedur peradilannya? serta pertanyaan-pertanyaan lain yang penting untuk dipenuhi agar tidak terjadi kekosongan hukum yang dapat menimbulkan ketidakpastian. Asas kepastian sebagai asas etika ini memiliki substansi dengan asas-asas Sustainable Development, Polliter Pay principle, Principle of Preventive Action, The Precautionary Principle, Sovereign Rights and 
Environmental Responsibility, serta Access to Environmental Information, Public Participation in Environmental Decision, Equal Access and Non-Discrimination.

\section{Asas kemanfaatan}

Manfaat sebagai salah satu tujuan dari norma hukum penting menjadi asas yang membangun sistem hukum etika. Hal ini selain memperkuat eksistensi asas-asas lain khususnya yang beririsan langsung dengan tujuan pembentukan hukum etika, asas kemanfaatan juga menghadirkan hukum sebagai instrumen yang solutif. Karakteristik preskriptif dari norma hukum mendorong perlunya capaian dan perubahan baik secara positif maupun negatif (reward and punishment). Selain itu jika menggunakan dimensi utilitarianisme dengan adagium khas the greatest happiness of the greatest number menjadikan hukum etika dapat menghadirkan cita hukum tidak hanya bagi pihak yang terikat langsung namun juga berdampak pada kepentingan masyarakat. Hal ini berarti kepentingan yang lebih banyak, lebih luas dan lebih jangka panjang kedepan harus dihadirkan dalam setiap produk sistem hukum etika agar produk tersebut menghasilkan pengaturan hingga putusan yang lebih berdampak struktural. Kemanfaatan sebagai asas etika memiliki substansi yang sama dengan seluruh asas baik Sustainable Development, Inter-generational Equity, Intra-generational Equity, Polliter Pay principle, Principle of Preventive Action, The Precautionary Principle, Sovereign Rights and Environmental Responsibility dan Access to Environmental Information, Public Participation in Environmental Decision, Equal Access and Non-Discrimination.

\section{Asas keseimbangan}

Setiap perbuatan yang melanggar norma hukum akan menghadirkan ketimpangan sehingga terjadi ketidakseimbangan baik secara normatif maupun empiris. Asas ini menekankan pada pentingnya menjaga dan mengembalikan kembali titik keseimbangan atau equilibrium atas implementasi hukum etika baik secara preventif maupun represif. Preventif artinya asas keseimbangan berperan memberikan porsi yang berimbang dalam hal yang substansial dan primer agar implementasi hukum etika dapat dijalankan bersama oleh pihak yang terikat melalui penyusunan hukum hingga sosialisasi serta edukasi yang terbaik. Pun pada perspektif represif berupa penjatuhan sanksi atas pelanggaran hukum etika juga harus dilandasi pada asas keseimbangan yang berarti putusan tersebut mempertimbangkan pulihnya kembali suatu keadaan baik secara pribadi maupun institusi yang telah diciderai atau dilanggar. Asas etika ini memiliki substansi sebagaimana asas terkait Sustainable Development, Inter-generational Equity, Intra-generational Equity, dan Sovereign Rights and Environmental Responsibility.

\section{Asas keterbukaan}

Hukum etika yang secara sistemik terbentuk dari norma hukum membutuhkan transparansi dan keterbukaan agar implementasi dan tujuan hukumnya dapat dicapai. Hal ini selain menegaskan asas-asas lain seperti kejelasan tujuan, kemandirian, keadilan juga berperan menghadirkan check and balances secara normatif agar produk hukum yang dikeluarkan oleh pihak yang otoritatif memiliki rasa keadilan yang konkret baik baik pihak yang terikat secara langsung maupun masyarakat secara umum. Keterbukaan dalam hal ini juga berkaitan dengan profesionalisme yang dijalankan oleh suatu institusi dalam mengimplementasikan keseriusannya menegakkan hukum termasuk hukum etika melalui kode etik masing-masing. Pada tataran implementasi di peradilan etik, asas keterbukaan 
asalnya merupakan hal yang menjadi default sebagai sarana pengawasan dan kontrol publik terhadap institusi. Akan tetapi keterbukaan dalam peradilan etika tersebut juga dikembalikan pada pengaturan prosedural dan mekanisme yang telah diatur dalam peraturan court of ethics dari masing-masing kelembagaan dengan mempertimbangkan asas-asas lain khususnya seperti kemanfaatan dan perlindungan. Hal ini berarti terbuka atau tertutupnya suatu persidangan etik tidak menjadi indikator tunggal dari baik atau buruknya mekanisme tersebut namun juga dilandasi pada kepentingan yang lebih jauh dan berdampak baik bagi masyarakat, institusi maupun pihak yang terkait. Secara substansial asas etika ini memiliki relasi dengan asas seperti Sustainable Development, Polliter Pay principle, Sovereign Rights and Environmental Responsibility dan Access to Environmental Information, Public Participation in Environmental Decision, Equal Access and Non-Discrimination,

\section{Asas perlindungan}

Norma hukum pada hukum etika sebagai instrumen sosial secara langsung dapat memberikan suatu jaminan dan perlindungan. Hal ini disebabkan terdapat norma yang mengatur hak dan kewajiban dari suatu pihak terkait dengan perbuatan yang bersifat spesifik. Perlindungan hukum tersebut secara konkret juga dapat dipertanggungjawabkan serta diuji termasuk digunakan sebagai landasan mempertahankan hak dalam setiap upaya penegakkan hukum etika. Asas perlindungan secara implementatif juga merupakan aplikasi dari perlindungan hak asasi manusia maupun hak-hak fundamental lain yang terikat dengan profesi. Hal ini memberikan perlindungan baik secara individu maupun karir dari seseorang yang melanggar hukum etika dalam kode etik namun pada sisi yang lain juga memberikan perlindungan terhadap institusi yang menaunginya temasuk perlindungan masyarakat serta kepentingan umum. Pelaksanaan dari asas perlindungan tentu memerlukan kebijaksanaan dan kearifan dari institusi peradilan etik dalam rangka menimbang maslahat atau kebermanfaatan mana yang hendak dicapai dengan sebaik-baik serta seadil-adilnya. Asas etika ini secara substansial memiliki kandungan yang esensial dengan seluruh asas hukum lingkungan mengingat salah satu tujuan asas hukum tersebut adalah melindungi kepentingan seluruh hal baik manusia, lingkungan, masa kini hingga masa depan.

\section{Implementasi Etika dan Asasnya dalam Negara Indonesia}

Indonesia sebagai negara yang menggunakan hukum sebagai instrumen otoritatif dalam pengaturan lingkungan hidup secara faktual, historis maupun sosiologis memiliki kondisi yang menjadikan cita hukum dalam konstitusi khususnya pada konteks lingkungan hidup sebagai hak asasi sebagaimana diatur dalam Pasal 28H ayat (2) Undang-Undang Dasar Negara Republik Indonesia Tahun 1945 maupun sarana mewujudkan kesejahteraan pada Pasal 33 ayat (3) dan (4). Implementasi secara substansial atas asas-asas umum etika hukum lingkungan membutuhkan dorongan kesadaran secara internal yang berasal dari pihak yang menundukkan dan mengikatkan diri pada sistem hukum etik tersebut. Sementara tantangan implementasi formil dengan belum adanya pengaturan yang jelas terkait asas-asas umum etika hukum lingkungan setidaknya dapat diupayakan melalui intervensi eksternal khususnya pendekatan yuridis. Hal inilah yang memerlukan dorongan secara simultan oleh seluruh pihak agar tantangan implementasi baik substansial dan formil hukum etika dapat direalisasikan secara menyeluruh serta berkelanjutan di negara hukum Indonesia. Kebutuhan untuk menentukan ius constituendum atas hukum lingkungan 
dan politik hukumnya memerlukan etika yang dikonkretkan khususnya terkait perbaikan budaya hukum lingkungan disamping substansi pengaturan hukum lingkungan (Said \& Yati, 2020).

Penerapan hukum etika secara langsung berkaitan dengan norma hukum lain yang menjadi payung sekaligus landasan yang dalam hal ini adalah hukum negara. Negara sebagai entitas yang kuat secara sistemik dapat memberikan pengaruh dan dampak bagi tumbuh kembangnya hukum etika di wilayahnya. Hal ini secara konkret dapat direalisasikan dengan pengaturan perihal hukum etika yang diatur melalui peraturan perundang-undangan. Indonesia sendiri telah merealisasikan implementasi ini pada beberapa bidang yang berkaitan dengan kepentingan masyarakat melalui pengaturan terkait dengan amanat untuk membentuk suatu sistem hukum etika. Intervensi negara dalam hal memerintahkan penyusunan perangkat-perangkat hukum etika baik kode etik dan institusi peradilan etik atau sejenis menunjukkan betapa negara dapat secara konkret bersumbangsih dalam mempengaruhi sistem hukum etika di masyarakat.

Tantangan implementasi hukum etika di Indonesia pada perspektif substansial dapat diatasi setidaknya dengan upaya-upaya kultural dan struktural perihal pentingnya membangun serta menegakkan kewibawaan hukum etika baik di masyarakat maupun institusi. Hukuman atau punishment maupun sanksi etik tidak jarang dipandang dan dianggap sebelah mata oleh beberapa kalangan sehingga hal tersebut seakan hanya berfungsi sebagai stempel semata tanpa menghadirkan dampak jera pada pelaku yang melanggar.

Pada dimensi penguatan budaya hukum lingkungan dalam rangka menegaskan arah politik hukum lingkungan secara ius constituendum maka hal yang perlu dikawal adalah aspek edukasi atau pendidikan. Edukasi dalam konteks lingkungan hidup merupakan instrumen penting dalam membentuk bahkan merubah fundamental dari persepsi dan perilaku manusia terhadap lingkungan (Hudha, Husanah, \& Rahardjanto, 2019).

Indonesia sebagai negara hukum dengan perangkat-perangkat yuridisnya dapat mengimplementasikan hukum etika secara komprehensif di setiap dimensi berbangsa dan bernegara. Hal ini secara konstitusional sebenarnya telah diberi ruang khususnya bagi pengembangan nilai moral atau etika dalam berbangsa jika dilandasi pada amanat tujuan bernegara Indonesia yang terkandung dalam Pembukaan Undang-Undang Dasar Negara Republik Indonesia Tahun 1945 khususnya pada konteks "kemanusiaan yang adil dan beradab". Sebagaimana dipahami bahwa Pembukaan Undang-Undang Dasar suatu negara memiliki tujuan dan pesan baik berupa identitas jati diri suatu negara termasuk cita-cita tujuan bernegara (Orgard, 2010). Hal ini menunjukkan bahwa cita konstitusi yang mencerminkan moral values dari negara hukum Indonesia harus diaplikasikan secara sistemik dalam peraturan perundang-undangan dibawahnya. Dengan kata lain pengaturan tentang hukum etika secara konkret implementasinya dapat digantungkan pada konstitusi dan regulasinya dilindungi melalui peraturan perundang-undangan maupun perangkat sistem hukum lain.

Pelembagaan hukum etika menjadi salah satu implementasi konkret yang dapat didukung oleh peraturan perundang-undangan pada seluruh institusi dan lembaga baik publik, private maupun sosial kemasyarakatan. Tentu hal ini juga memiliki tantangan dan hambatan turunan baik berupa pemahaman maupun pelaksanaan yang memerlukan sumber daya agar hukum etika dengan asas-asasnya dapat dibentuk dengan sebaik-baiknya. Namun kendala tersebut bukan menjadi alasan untuk tidak menerapkan dan mengaplikasikan hukum etika beserta asas-asas umumnya pada suatu lembaga terlebih ketika hal tersebut memiliki relevansi formil yang diperintahkan secara konstitiusional.

166 | Article History, Submitted 10 September 2021 - Revision Required 19 September 2021 - Accepted 30 September 2021. 
Hal ini sebagaimana diatur dalam Bab V tentang Penutup Ketetapan Majelis Permusyawaratan Perwakilan Republik Indonesia Nomor VI/MPR/2001 tentang Etika Kehidupan Berbangsa yang berbunyi dengan secara subtansial memerintahkan "Etika kehidupan berbangsa ini disusun untuk diamalkan oleh seluruh warga bangsa". Pengaturan etika kehidupan berbangsa dalam Tap MPR tersebut sebagaimana telah dipaparkan pada bagian sebelumnya di penelitian ini menunjukkan bahwa hukum etika dapat di internalisasi, disosialisasikan dan di implementasikan secara sistemik dan tentu bertahap pada masyarakat di Indonesia.

Tap MPR Nomor VI/MPR/2001 masih memilliki keberlakuan secara hierarkis, sebagaimana diatur dalam Pasal 7 huruf b Undang-Undang Nomor 12 Tahun 2011 tentang Pembentukan Peraturan Perundang-Undangan yang diubah dengan Undang-Undang Nomor 15 Tahun 2019 tentang Perubahan atas Undang-Undang Nomor 12 Tahun 2012 tentang Pembentukan Peraturan Perundang-Undangan. Hal ini dilandasi pada ketentuan Pasal 4 angka 8 yang menerangkan bahwa Ketetapan MPR tersebut masih berlaku hingga terbentuknya undang-undang yang mengatur, sementara hingga saat penelitian ini ditulis belum ada undang-undang yang mengatur perihal materi Tap MPR Nomor VI/MPR/2001 tentang Etika Kehidupan Berbangsa.

Maka dari itu jika melandasi amanat konstitusional dari Ketetapan MPR Nomor VI/MPR/2001 tersebut, dapat menjadi dasar hukum bagi negara untuk menyusun undang-undang yang berkaitan dengan hukum etika secara khusus. Hal ini disebabkan hukum etika baik secara materiil maupun formil dapat menyajikan serta membentuk tujuan positif baik dari perspektif norma hukum maupun norma etika dalam rangka mewujudkan cita-cita berbangsa dan bernegara sebagaimana juga diharapkan oleh Tap MPR Nomor VI/MPR/2001 tentang Etika Kehidupan Berbangsa yang sejalan dengan cita negara dalam konstitusi.

\section{PENUTUP}

Perdebatan dalam memposisikan hukum dengan etika semakin menyempit terlebih terjadi paradoks-paradoks pada karakter hukum secara kontemporer. Hukum yang disatu sisi dipandang "bebas nilai" dan "bebas moral" mengalami krisis pada (1) bentuk hukum yang semakin beririsan antar bidang perdata, pidana, administrasi dan lainnya, serta (2) semakin perlunya etika pada sistem hukum yang mendorong adanya "re-moralisasi" (Douzinas \& Warrington, 1994). Perkembangan dan kemajuan zaman secara langsung menuntut kecepatan dan inovasi dari instrumen masyarakat termasuk hukum. Hal inilah yang mendorong pentingnya eksistensi hukum etika sebagai salah satu instrumen yang bersifat prinsipil dan diharapkan mampu menjawab kebutuhan masyarakat secara substansial khususnya dalam dimensi lingkungan. Etika lingkungan sebagai hubungan etis antara manusia dengan lingkungan hidupnya memerlukan pengaruh secara masif termasuk pada perspektif hukum.

Hukum etika dapat dan harus melahirkan legal optimism sebagai usaha mengembangkan doktrin-doktrin hukum yang eksis melalui mengulas kehendak normatif sekaligus menyelaraskan dengan kontekstual sosial hukum (Dagan, 2004). Hal ini yang diharapkan juga dalam implementasinya dalam aspek hukum lingkungan. Optimisme hukum yang dibangun melalui hukum etika khususnya lingkungan hidup secara konkret menunjukkan bahwa norma etika yang sifatnya soft dengan norma hukum dengan sifat hard dapat dipadukan dalam rangka memaksimalkan potensi instrumental hukum guna mewujudkan tujuannya. Kebermanfaatan dari hukum etika serta asas-asasnya dalam perspektif lingkungan hidup diharapkan mampu 
memperkuat penegakkan hukum lingkungan sebagaimana ius constituendum yang ada dalam sistem hukum lingkungan di Indonesia.

Asas-asas umum etika hukum lingkungan secara substansial telah eksis tersebar dan terinternalisasi dalam asas hukum lingkungan yang bersifat universal maupun nasional sebagaimana diatur secara positif. Terdapat beberapa asas-asas yang fundamental dan penting seharusnya ada dalam etika hukum lingkungan baik secara materiil berupa kode etik maupun secara formil yakni peradilan etik. Asas-asas tersebut antara lain asas kejelasan tujuan, asas kemandirian, asas keadilan, asas kepastian, asas kemanfaatan, asas keseimbangan, asas keterbukaan serta asas perlindungan. Delapan asas tersebut dapat diaplikasikan secara kolaboratif tanpa perlu dipertentangkan asas mana yang relevan diimplementasikan secara formil sementara yang lain tidak mengingat asas etika tersebut juga memiliki substansi yang senapas dengan asas hukum lingkungan.

Masih berlakunya Ketetapan Majelis Permusyawaratan Rakyat Republik Indonesia atau Tap MPR Nomor VI/MPR/2001 tentang Etika Kehidupan Bernegara secara substansial dan secara formil memberikan amanat kepada negara baik secara langsung untuk segera membentuk undangundang yang mengatur terkait dengan keberadaan etika yang dipositifkan atau hukum etika. Hal tersebut secara langsung menjawab tantangan implementasi etika hukum lingkungan dan asas-asas umumnya untuk diberlakukan di Indonesia secara formil melalui pendekatan legal-yuridis maupun institusional.

Sebagai catatan tambahan bahwa dalam menjaga relasi antara norma hukum dan norma etika dalam etika hukum lingkungan maka diperlukan upaya-upaya evaluatif dalam mengkaji perspektif hukum etika terutama dalam menemukan hukum etika yang progresif. Hal ini tidak hanya didapatkan melalui analisis yang bersifat menyeluruh atas asas maupun nilai dari hukum etika yang hakikatnya memiliki karakter spesifik namun juga memerlukan penelitian bagaimana hukum etika dari bidang-bidang yang berbeda menghadapi permasalahan konkret (Syed, 2017).

Penelitian dan kajian secara dialektis tentang topik yang masih terbatas pembahasannya ini membutuhkan upaya learning by doing dengan mendorong semakin banyak elemen masyarakat atau civil society untuk mengenal serta mendalami etika hukum lingkungan sehingga dapat menghasilkan evaluasi dan pembacaan yang lebih komprehensif tentang norma hukum, norma etika maupun etika hukum dengan perspektif lingkungan. Ilmu pengetahuan sendiri merupakan hal konkret yang mampu mendorong pada ecological rationality sebagai pola pikir yang transformative (Tarlock, 1996). Hal inilah yang menjadi saran yang konkret dari penulis sebagai upaya serius dalam membangun sistem hukum yang komprehensif dan struktural melalui proses pengayaan multidimensional baik hukum dengan bidang ilmu lain maupun antara hukum dengan norma-norma sejenisnya guna mewujudkan cita hukum lingkungan di Indonesia.

\section{REFERENCES}

Aristotle. (2000). Nicomachean Ethics. Oxford: Cambridge University Press. https://doi.org/10.1017/CBO9780511802058

Asshiddiqie, J. (2009). Pengantar Ilmu Hukum Tata Negara Jilid I. Jakarta: Sekretariat Jenderal dan Kepaniteraan Mahkamah Konstitusi RI.

Asshiddiqie, J. (2015). Peradilan Etik dan Etika Konstitusi. Jakarta: Sinar Grafika.

Atighetchi, D. (2007). Islamic Bioethics : Problems and Perspectives. Dordrecht: Springer.

Bondolfi, A., \& Nye, J. (2000). Ethics, Law and Legislation: The Institutionalisation of Moral 168 | Article History, Submitted 10 September 2021 - Revision Required 19 September 2021 - Accepted 30 September 2021. 
Reflection. Ethical Theory and Moral Practice, 3(1), 27-37.

Chroust, A. H., \& Osborn, D. L. (1942). Aristotle's Conception of Justice. Notre Dame Law Review, 17(2), 129-143.

Dagan, H. (2004). The Law and Ethics of Restitution. New York: Cambridge University Press.

Douzinas, C., \& Warrington, R. (1994). Justice Miscarried: Ethics and Aesthetics in Law. Hertfordshire: Harvester Wheatsheaf.

French, F. C. (1893). The Concept of Law in Ethics. The Philosophical Review, 2(1), 35-53. https://doi.org/10.2307/2176068

Head, M., \& Man, S. (2005). Law in Persoective : Ethics, Society and Critical Thinking. Sydney: UNSW Press.

Hudha, A. M., Husanah, \& Rahardjanto, A. (2019). Etika Lingkungan: Teori dan Prakti Pembelajarannya. Malang: Universitas Muhammadiyah Malang Press.

Luban, D. (2007). Legal Ethics and Human Dighnity. New York: Cambridge University Press.

Lyons, D. (1984). Ethics and The Rule of Law. New York: Cambridge University Press.

Marzuki, P. M. (2013). Pengantar Ilmu Hukum (Revisi). Jakarta: Prenada Media.

Moore, G. E. (2002). Principia Ethica. Cambridge: Cambridge University Press.

Orgard, L. (2010). The Preamble in Constitution Interpretation. I-CON, 8(4), 714-738.

Pufendorf, S. (2009). Two Books of The Elements of Universal Jurisprudence. Indianapolis: Liberty Fund.

Quasem, M. A. (1988). Etika Al Ghazali. Bandung: Penerbit Pustaka.

Ross, D., \& Stratton-Lake, P. (2007). The Right and The Good. Oxford: Oxford University Press. https://doi.org/10.1093/0199252653.001.0001

Said, M. Y., \& Yati, N. (2020). Paradigma Filsafat Etika Lingkungan dalam Menentukan Arah Politik Hukum Lingkungan. Al' Adl Jurnal Hukum, 12(1), 39-60.

Santoso, A. (2012). Hukum, Moral dan Keadilan. Jakarta: Kencana.

Soper, P. (2002). The Ethics if Deference: Learning from Law's Morals. New York: Cambridge University Press.

Syarif, L. M., \& Wibisana, A. G. (2015). Hukum Lingkungan : Teori, Legislasi dan Studi Kasus. Jakarta: Kemitraan Partnerhip.

Syed, M. U. (2017). Coercion and Responsibility in Islam : A Study in Erhics and Law. Oxford: Oxford University Press.

Tarlock, A. (1996). Environmental Law : Ethics or Science? Duke Environment Law and Policy Forum, 7(193), 193-223.

Ward, S. J. A. (2011). Ethics and Media : An Introduction. Madison: Cambridge University Press. https://doi.org/10.1017/CBO9780511977800 